\title{
Karakteristik Wanita Tuna Susila (WTS) dan Pengetahuan Tentang HIV/AIDS WTS di Panti Rehabilitasi Jawa Barat
}

\section{Characteristic of Prostitutes in The Rehabilitation Program in West Java and Their Knowledge of HIV/AIDS}

\author{
Sudaryat $^{1 *}$, Amri Jahi ${ }^{2}$, dan Prabowo Tjitropranoto ${ }^{2}$ \\ ${ }^{1}$ Staf Dinas Pendidikan Kota Sukabumi \\ ${ }^{2}$ Departemen Sains Komunikasi dan Pengembangan Masyarakat, \\ Fakultas Ekologi Manusia, Institut Pertanian Bogor
}

\begin{abstract}
The characteristics of prostitutes were predicted to be related to their knowledge of HIV/AIDS. The reseach was designed as a descriptive survey involving 100 respondent/prostitutes from the Rehabilitation Center, selected through a Proportional Random Sampling. The collected data were put into a descriptive-qualitative analysis and the test Concordation Kendall W. The reseach has the following result: the average age of prostitutes is 26, they are maried, have the formal education of an elementary level, level of income 2.182.900 rupiahs, medium intrinsic motivation, low extrinsic motivation, have a perception of an ideal life for woman, working experience up to 1 year, never have violent sexual treatment, medium economic condition, low level of obedience to social norm, no social effect of origin, long distance to workplace, medium intensity of interaction with other prostitutes, moderate sexual teaching, high intensity of contact with costumers, and low perception of hedonism sex. In general the prostitutes know about HIV/AIDS. There is degree of similarity among them concerting the various characteristics of 10 ranking areas of HIV/AIDS knowledge, in which they are interested. As a conclusion, of the ten knowledge areas, there are three main areas of knowledge considered the most important: 1) the danger of HIV/AIDS, 2) method of transmission, and 3) preventing method.
\end{abstract}

Key words: knowledge, characteristic, prostitutes and rehabilitation

\section{PENDAHULUAN}

Menyadarkan para wanita tuna susila (WTS) tentang bahaya Human Imunodeficiency Virus (HIV) dan Aquaired Imuno Deficiency Syndrom (AIDS) itu perlu dilakukan untuk menjaga kesehatan masyarakat. Hal ini penting karena para WTS itu dapat berperan sebagai penular yang sangat potensial untuk menyebarkan kuman penyakit tersebut kepada orang-orang yang belum terinfeksi.

WTS yang sadar akan bahaya HIV/AIDS hendaknya melakukan beberapa tindakan untuk mencegah penularan penyakit tersebut. Pertama, menjaga dirinya agar tidak tertular kuman HIV/AIDS. Kedua, tindakan

\footnotetext{
* Korespondensi penulis. Telepon: 08128155615 E-mail: sudaryat@yahoo.com
}

preventif lain yang perlu dilakukan WTS, baik yang merasa atau diduga telah terinfeksi virus ini adalah memeriksakan dirinya kepada dokter atau petugas kesehatan secara berkala dengan melakukan tes darah, urine atau sel pipi untuk mengecek adanya antibodi HIV/AIDS dan menentukan gejala, apakah dirinya telah tertular kuman tersebut atau tidak.

Upaya tindak lanjut yang penting dilakukan oleh WTS yang sudah terinfeksi virus, adalah memberitahukannya kepada orang lain terutama orang-orang yang dekat dengannya. Upaya ini dilakukan guna mencegah penularan HIV/AIDS lebih luas. Demikian pula seandainya mereka telah terjangkit penyakit kelamin lain seperti genital warts atau chlamidia, seharusnya untuk sementara tidak melakukan hubungan seksual 


\section{Jurnal Penyuluhan, Maret 2009 Vol. 5 No. 1}

dengan siapapun, sampai penyakitnya dinyatakan sembuh oleh dokter atau petugas kesehatan. Hal ini perlu dilakukan karena penyakit kelamin lain yang diderita oleh WTS itu akan memperbesar kemungkinan tertular kuman-kuman HIV/AIDS jika melakukan hubungan seksual dengan pengidap HIV/AIDS.

Kesadaran ini sangat penting dimiliki oleh para WTS, baik yang sudah terinfeksi HIV maupun belum. Mereka perlu berkonsultasi secara berkala dengan petugas kesehatan, melaporkan gejala-gejala penyakit tersebut dan mendapatkan nasihat (conselling) dari dokter atau petugas kesehatan itu. Dengan demikian mereka dapat menjaga kesehatan dirinya, dan mencegah penularan HIV/AIDS lebih lanjut.

Tindakan paling baik dilakukan oleh WTS yang tahu tentang kesehatan alat reproduksi (kespro), penyakit menular seksual (PMS), dan bahaya penyakit HIV/AIDS adalah berhenti melakukan praktek hubungan seksual di luar pernikahan (ekstramarital) dan tahui HIV/AIDS dan bahayanya pada kesehatan manusia? Seberapa jauh tingkat keeratan hubungan antara karakteristik para WTS itu dengan pengetahuan mereka tentang HIV/AIDS dan bahayanya pada kesehatan manusia? Penelitian ini bertujuan: (1) mengidentifikasi karakteristik individu para WTS yang sedang direhabilitasi di Panti Rehabilitasi Sosial Wanita Jawa Barat. (2) mengidentifikasi tingkat pengetahuan para WTS itu tentang HIV/AIDS dan bahayanya pada kesehatan manusia, dan (3) menghitung tingkat keeratan hubungan antara karakteristik para WTS itu dengan pengetahuan mereka tentang HIV/AIDS dan bahayanya pada kesehatan manusia.

\section{METODOLOGI PENELITIAN}

Populasi dalam penelitian adalah semua WTS yang sedang direhabilitasi di panti rehabilitasi sosial wanita Jawa Barat (Tabel 1).

Tabel 1. Populasi dan sampel WTS yang Mengikuti Diklat di Panti Rehabilitasi Sosial Bina Sosial Wanita Jawa Barat, Periode Juni - September 2006

\begin{tabular}{llcc}
\hline No & Nama Lembaga Rehabilitasi & Populasi & Sampel \\
\hline 1 & PSKW Marga Rahayu & 40 & 30 \\
2 & BPSWTS Silih Asih & 100 & 70 \\
\hline & Jumlah & 140 & 100 \\
\hline
\end{tabular}

meninggalkan pekerjaan sebagai WTS. Namun maukah mereka melakukan hal tersebut, dan mampukah mereka melaku-kannya dengan mengisolasi diri terhadap penularan HIV/AIDS ? Maukah para WTS itu melaksanakan tanggungjawab sosial pada tindakan mereka yang berdampak buruk pada masyarakat luas?

Pertanyaan-pertanyaan dan pertimbangan-pertimbangan semacam inilah yang memiliki dampak yang luas pada kesehatan masyarakat, yang mendorong dilakukannya penelitian ini. Masalah yang dirumuskan dalam penelitian ini adalah: Apa karakteristik individu para WTS yang sedang direhabilitasi di Panti Rehabilitasi Sosial Wanita Jawa Barat? Seberapa jauh para WTS itu menge-
Karakteristik responden terdiri dari peubah: 1) umur, 2) status perkawinan, 3) pendidikan formal, 4) tingkat pendapatan, 5) motivasi instrinsik menjadi WTS, 6) motivasi ekstrinsik menjadi WTS, 7) persepsi untuk hidup yang ideal, 8) lamanya menjadi WTS, 9) mendapat perlakuan kekerasan seksual, 10) keadaan ekonomi keluarga, 11) kepatuhan terhadap norma susila, 12) pengaruh lingkungan sosial daerah asal, 13) jarak ke tempat sebagai WTS, 14) intensitas interaksi dengan WTS lain, 15) yang melatih/ mengajari tentang seksual, 16) intensitas hubungan dengan pelanggan, dan 17) persepsi seks sebagai hedonisme.

Pengetahuan responden tentang HIV/AIDS merupakan tingkat kemampuan kognitif yang 
dimiliki responden tentang HIV/AIDS yang terdiri dari: (1) pengertian Human Immunodeficiency Virus (HIV) yaitu virus penyebab sindroma AIDS, Acquired Immuno Deficiency Syndrome (sekumpulan gejala penyakit, yang timbul karena turunnya kekebalan tubuh) Acquired artinya didapat, bukan merupakan penyakit keturunan, immuno berarti sistem kekebalan tubuh, deficiency artinya kekurangan, sedangkan syndrome adalah kumpulan gejala. AIDS merupakan fase akhir dari infeksi virus HIV. (2) penyebab AIDS dan Infeksi Sekunder sebagai Akibat AIDS: HIV yaitu virus penyebab terjangkitnya HIV, yang menghancurkan sistem kekebalan tubuh penderita dan dapat menyebabkan penyakit AIDS. AIDS merupakan suatu kumpulan gejala berbagai penyakit yang disebabkan oleh virus yang mempengaruhi sistem kekebalan.

Sistem kekebalan menjadi tidak mampu memerangi infeksi. (3) cara Penularan; HIV bisa menular lewat 3 cara, (a) melalui hubungan seksual dengan seseorang yang sudah terinfeksi HIV tanpa memakai kondom, (b) melalui transfusi darah, transplantasi organ tubuh, pemakaian alat-alat yang telah tercemar HIV, (c) melalui ibu yang terinfeksi HIV kepada janin yang dikandungnya atau kepada bayi yang disusuinya. (4) cara Pencegahan; Tindakan yang harus dilakukan untuk mencegah penularan HIV seperti: (a) tidak melakukan hubungan seks dengan pengidap HIV/AIDS atau orang yang termasuk kelompok perilaku risiko tinggi, (b) tidak melakukan hubungan seks dengan banyak pasangan, (c) menggunakan kondom dari awal sampai selesai, apabila melakukan hubungan seks dengan pasangan baru atau anggota kelompok berisiko tinggi, (d) mengobati penyakit kelamin secara tuntas. (5) pengetahuan kesehatan reproduksi (Kespro). Pengetahuan tentang kesehatan seksual dan reproduksi, dan penyakit menular seksual (PMS), pengetahuan tentang organ reproduksi dan fungsinya, perilaku seksual yang menyebabkan kehamilan, aborsi, dan penyakit kelamin. (6) bahaya HIV/AIDS bagi kesehatan manusia. Selain bahaya yang mengancam pada kesehatan jasmani, penderita HIV/AIDS sering mengalami masalah-masalah psikologis (kecemasan, depresi, rasa bersalah, dan timbulnya dorongan untuk bunuh diri) sehingga dapat menyebabkan kematian. akibat HIV/AIDS. Dikucilkan oleh rekanrekan/masyarakat, diskriminasi, dirumah diusir dan dikantor diberhentikan dari pekerjaan. (8) hubungan Sosial Dengan Penderita AIDS. Berbagi (memakai) baju, handuk dan toilet, penggunaan peralatan yang sama (misalnya telepon), makan dari perkakas yang sama, kolam renang bersama-sama pengidap HIV dalam satu tempat, merawat orang yang terinfeksi HIV, mencuci kloset, sprei dan lainnya yang digunakan pengidap HIV. (9) dampak Sosial Ekonomi AIDS. Dari sisi ekonomi HIV/AIDS telah menjadi masalah karena mahalnya biaya perawatan, berkurangnya usia produktif, kehilangan sumber daya manusia yang pada akhirnya dapat menjadi faktor penyebab kemiskinan. (10) hubungan Narkoba dengan AIDS. Bahaya narkoba dalam menyebarkan penyakit HIV/AID, bila narkobais tidak peduli terhadap penggunaan jarum suntik yang berisiko menyebarluaskan virus HIV.

\section{HASIL DAN PEMBAHASAN}

\section{Karakteristik Responden}

Deskripsi karakteristik responden seperti yang ditunjukkan pada Tabel 2 memperlihatkan bahwa rata-rata umur WTS 26,4 tahun, pernah menikah, pendidikan forrmalnya rendah, pendapatan rata-rata $\mathrm{Rp}$ 2,4 juta per bulan, dan rata-rata telah menjalani usahanya selama setahun. 
Jurnal Penyuluhan, Maret 2009 Vol. 5 No. 1

Tabel 2. Karakteristik Responden Menurut Kategori

\begin{tabular}{|c|c|c|c|c|}
\hline No & Karakteristik & Kategori & Rata-rata & $\%$ \\
\hline \multirow[t]{3}{*}{1} & Umur & Muda (13-23 tahun) & & 31 \\
\hline & & Sedang (24-28 tahun) & 26,4 th & 37 \\
\hline & & Tua $\quad$ (29-44 tahun) & & 32 \\
\hline \multirow[t]{3}{*}{2} & Status Perkawinan & Belum menikah & & 22 \\
\hline & & Pernah menikah & - & 56 \\
\hline & & Menikah & & 22 \\
\hline \multirow[t]{3}{*}{3} & Pendidikan Formal & Rendah (2-6 tahun) & & 38 \\
\hline & & Sedang (6,5-10 tahun) & 8,35 tahun & 32 \\
\hline & & Tinggi (11- 15 tahun $)$ & & 30 \\
\hline \multirow[t]{3}{*}{4} & Tingkat Pendapatan & Rendah (450 ribu - 1.200.ribu) & & 32 \\
\hline & & Sedang(1.250 ribu - 3.100 ribu $)$ & Kp & 33 \\
\hline & & Tinggi (3.150.ribu -7.600 ribu) & $2.382 .900,-$ & 35 \\
\hline \multirow[t]{3}{*}{5} & Motivasi Instrinsik & Rendah $(7-11)$ & & 33 \\
\hline & & Sedang (12-16) & Skor 14,17 & 35 \\
\hline & & Tinggi $(17-28)$ & & 32 \\
\hline \multirow[t]{3}{*}{6} & Motivasi Ekstrinsik & Rendah (4-8) & & 35 \\
\hline & & Sedang $\quad(9-10)$ & 9,32 & 33 \\
\hline & & Tinggi $\quad(11-20)$ & & 32 \\
\hline \multirow[t]{3}{*}{7} & Persepsi hidup ideal & Kurang ideal & & 30 \\
\hline & & $(13-16)$ & 14,3 & 30 \\
\hline & & Sangat ideal $\quad(17-21)$ & & 40 \\
\hline \multirow[t]{3}{*}{8} & Lamanya jadi WTS & Tidak lama & & 33 \\
\hline & & (7-13 bulan) & 12 bulan & 32 \\
\hline & & Sangat lama $\quad$ (14-300 bulan) & & 35 \\
\hline \multirow[t]{3}{*}{9} & Mendapat perlakuan & Tidak pernah & & 76 \\
\hline & kekerasan seksual & Pernah $\quad$ (1-2 kali) & 1 kali & 14 \\
\hline & & (3-20 kali) & & 10 \\
\hline \multirow[t]{3}{*}{10} & Keadaan Ekonomi & Rendah (5-8) & & 35 \\
\hline & keluarga & Sedang $(9-11)$ & Skor: 9,51 & 38 \\
\hline & & Tinggi (12-14) & & 27 \\
\hline \multirow[t]{3}{*}{11} & Kepatuhan terhadap & Tidak patuh (4-6) & & 38 \\
\hline & norma & Patuh $(7-10)$ & Skor 8,17 & 38 \\
\hline & & Sangat patuh (22-31) & & 24 \\
\hline \multirow[t]{3}{*}{12} & Pengaruh Lingkungan & Tidak berpengaruh (8-16) & & 34 \\
\hline & Sosial Daerah Asal & Terpengaruh $(17-21)$ & Skor : 18,56 & 32 \\
\hline & & Sangat terpengaruh $(22-31)$ & & 34 \\
\hline \multirow[t]{3}{*}{13} & Jarak tempat bekerja & Dekat $\quad(0,1-1 \mathrm{~km})$ & & 33 \\
\hline & & Sedang $(1,5-2,5 \mathrm{~km})$ & $7,4 \mathrm{~km}$ & 32 \\
\hline & & Jauh $(3-100 \mathrm{~km})$ & & 35 \\
\hline \multirow[t]{3}{*}{14} & Intensitas Interaksi & Rendah (2-3 kali) & & 34 \\
\hline & dengan WTS lain & Sedang (4 kali) & 4 kali & 41 \\
\hline & & Tinggi (5-6 kali) & & 25 \\
\hline \multirow[t]{3}{*}{15} & OrangYang mengajari/ & Rendah (5-6 kali) & & 34 \\
\hline & melatih tentang seksual & Sedang (7-10 kali) & 9 kali & 40 \\
\hline & & Tinggi (11-21 kali) & & 26 \\
\hline \multirow[t]{3}{*}{16} & Intensitas hubungan & Rendah (2-3 kali) & & 26 \\
\hline & dengan pelanggan & Sedang (4-5 kali) & 5 kali & 36 \\
\hline & & Tinggi (6-10 kali) & & 38 \\
\hline \multirow[t]{3}{*}{17} & Persepsi seks & Rendah (4-5) & & 59 \\
\hline & hedonisme & Sedang $(6-10)$ & Skor: 7,8 & 13 \\
\hline & & Tinggi (11-21) & & 28 \\
\hline
\end{tabular}


Jurnal Penyuluhan, Maret 2009 Vol. 5 No. 1

Pengetahuan WTS tentang HIV/AIDS

Hasil penelitian hubungan pengetahuan responden di Panti Rehabilitasi Sosial Wanita Jawa Barat tentang HIV/AIDS dapat dilihat pada Tabel 3. hubungan dengan pelanggan rendah dan persepsi seks hedonisme rendah, rata-rata pengetahuan tentang HIV/AIDS yang dikuasai skor $=51,44$ atau 51,44 persen.

Kategori kedua: umur sedang, pernah menikah, pendidikan formal, tingkat penda-

Tabel 3. Pengetahuan Responden tentang HIV/AIDS

\begin{tabular}{llcc}
\hline No & Bidang Pengetahuan & Skor & Jenjang \\
\hline 1 & Bahaya HIV bagi kesehatan & 68,00 & 1 \\
2 & Cara penularan & 60,38 & 2 \\
3 & Cara pencegahan & 58,50 & 3 \\
4 & Pengertian & 57,00 & 4 \\
5 & Pengetahuan Kespro & 56,00 & 5 \\
6 & Akibat HIV/AIDS & 55,50 & 6 \\
7 & Hubungan sosial dengan penderita HIV/AIDS & 49,30 & 7 \\
8 & Penyebab AIDS dan infeksi sekunder & 45,40 & 8 \\
9 & Dampak sosial ekonomi AIDS & 42,00 & 9 \\
10 & Hubungan narkoba dengan AIDS & 38,00 & 10 \\
\hline & Rata-rata & 53,01 & \\
\hline
\end{tabular}

Pengetahuan tentang HIV/AIDS merupakan kemampuan kognitif dari enam kemampuan tersebut yaitu: pengertian (pengetahuan), pemahaman, aplikasi, analisis, sintesis dan evaluasi. Pengetahuan WTS tentang HIV/AIDS, terdiri atas: pengertian HIV/AIDS, penyebab AIDS dan infeksi sekunder sebagai akibat AIDS, cara penularan, cara pencegahan, pengetahuan kesehatan reproduksi (kespro), bahaya HIV/AIDS pada kesehatan manusia, akibat HIV/AIDS, hubungan sosial dengan penderita HIV/AIDS, dampak sosial ekonomi AIDS dan hubungan narkoba dengan HIV/AIDS.

Setelah dilakukan pengukuran terhadap kemampuan kognitif tentang HIV/AIDS, menggunakan skala interval, dengan skor maksimal $=100$, hasil penelitian pengetahuan WTS tentang HIV/AIDS, ditemukan tiga kategori.

Kategori pertama: umur muda, belum menikah, pendidikan formal rendah, tingkat pendapatan rendah, motivasi rendah, persepsi kurang ideal, tidak lama menjadi WTS, tidak pernah mendapat perlakuan kekerasan seksual, keadaan ekonomi keluarga kurang, tidak patuh terhadap norma, tidak terpengaruh lingkungan sosial daerah asal, jarak ke tempat bekerja dekat, intensitas interaksi dengan WTS lain rendah, diajari seks rendah, intensitas patan, motivasi sedang, persepsi hidup ideal, lama menjadi WTS, pernah mendapat perlakuan kekerasan seksual, keadaan ekonomi keluarga sedang, patuh terhadap norma, terpengaruh lingkungan sosial daerah asal, jarak ke tempat bekerja sedang, intensitas interaksi dengan WTS lain sedang, yang mengajari seks sedang, intensitas hubungan dengan pelanggan sedang, dan persepsi seks hedonisme sedang, rata-rata pengetahuan tentang HIV/AIDS yang dikuasai dengan skor $=52,73$ atau 52,73 persen.

Kategori ketiga: umur tua, menikah, pendidikan formal tinggi, tingkat pendapatan tinggi, motivasi tinggi, persepsi sangat ideal, sangat lama menjadi WTS, sering mendapat perlakuan kekerasan seksual, keadaan ekonomi keluarga tinggi, sangat patuh terhadap norma, sangat terpengaruh lingkungan sosial daerah asal, jarak ke tempat bekerja sangat jauh, intensitas interaksi dengan WTS lain tinggi, yang mengajari seks tinggi, intensitas hubungan dengan pelanggan tinggi, dan persepsi seks hedonisme tinggi, rata-rata pengetahuan tentang HIV/AIDS yang dikuasai dengan skor 55,53 atau 55,53 persen.

Rata-rata pengetahuan mereka tentang HIV/AIDS, hanya dikuasai dengan skor = $53,01(53,01 \%)$. Hal ini menunjukkan bahwa 
Jurnal Penyuluhan, Maret 2009 Vol. 5 No. 1

tingkat pengetahuan WTS tentang HIV/AIDS masih cukup rendah.

\section{Hubungan Karakteristik WTS dengan Pengetahuan tentang HIV/AIDS}

Faktor umur merupakan salah satu karakteristik yang berpengaruh terhadap perilaku manusia. Sebagian besar responden berusia produktif. Menurut Bakir dan Manning (1984) umur produktif untuk bekerja di negara-negara berkembang umumnya antara 15-55 tahun. Kemampuan kerja seseorang dipengaruhi oleh tingkat umur. Keadaan ini disimpulkan bahwa responden dapat dikategorikan sebagai orang dewasa muda, sehingga masih berpeluang untuk meninggalkan atau bahkan menekuni pekerjaan ini, bergantung dari situasi dan kondisi ekonomi pada saat tersebut. Dari hasil uji Konkordansi Kendall $W$ antara umur WTS dengan pengetahuan tentang HIV/AIDS adalah $\mathrm{W}=0,91$ pada alfa 0,01 . Hasil analisis tersebut menggambarkan hubungan sangat nyata berpengaruhnya faktor umur pada pengetahuan WTS tentang HIV/AIDS

Status perkawinan memegang peran penting dalam kehidupan wanita. Hal ini terlihat dari sangat berpengaruhnya status perkawinan terhadap pengetahuan mereka tentang HIV/AIDS. Responden dengan status masih menikah dan pernah menikah banyak ditemukan dalam penelitian ini, yaitu tujuh puluh delapan persen, terdiri dari janda cerai hidup empat puluh delapan persen, bahkan dari sejumlah itu, ada yang pernah menikah sampai tujuh kali. Hanya sekitar delapan persen janda cerai mati, sedangkan selebihnya hanya dua puluh dua persen WTS dengan status masih menikah. Dengan seringnya kawin cerai menunjukkan pula bahwa mereka sulit mempertahankan rumahtangga seperti seharusnya karena sifat pekerjaannya. Analisis di atas menggambarkan tidak banyak perbedaan antara status pekawinan WTS, baik perempuan tanpa suami maupun masih bersuami banyak ditemukan sebagai WTS. Hal ini diduga ada faktor lain yang mempengaruhi, seperti kebebasan dan keleluasaan dalam rumahtangga untuk bertindak sendiri bagi wanita tanpa suami dengan motif utama adalah faktor ekonomi. Dari hasil uji Konkordansi Kendall $W$ antara status perkawinan WTS dengan pengetahuan tentang HIV/AIDS adalah $\mathrm{W}=0,88$ pada alfa 0,01 . Hasil analisis tersebut menggambarkan berpengaruh nyata positif faktor status perkawinan pada pengetahuan tentang HIV/AIDS.

Pendidikan berpengaruh terhadap perilaku seseorang. Pendidikan sebagai suatu proses yang bertujuan menghasilkan perubahan-perubahan perilaku dan menyadarkan manusia dari sifat-sifat buruk. Hasil analisis rata-rata pendidikan WTS adalah SD, bahkan ada yang tidak tamat tingkat sekolah dasar. Sesuai hasil penelitian Sriwidodo (1997) yang menyatakan disamping pendidikan WTS rendah ada juga yang tidak dapat membaca dan menulis huruf latin. Hasil uji Konkordansi Kendall $W$ antara tingkat pendidikan formal WTS dengan pengetahuan tentang HIV/AIDS adalah $\mathrm{W}=0,88$ pada alfa 0,01 , yang menggambarkan bahwa terdapat hubungan antara tingkat pendidikan formal yang dimiliki WTS dengan pengetahuan tentang HIV/AIDS, atau rendahnya pengetahuan tentang HIV/AIDS, mungkin karena pendidikannya yang rendah.

Tingkat pendapatan yang tinggi sangat berpengaruh terhadap perilaku. Dengan rataan tingkat pendapatan responden $\mathrm{Rp}$ 2.182.000,per bulan, bahkan lebih, diduga penghasilan responden cukup lumayan. Dengan demikian kebutuhan hidupnya merasa tercukupi. Namun tingkat pendapatan yang tinggi tidak dibarengi dengan tingkat pengetahuan WTS tentang HIV/AIDS yang baik; mungkin pendapatan yang tinggi ini lebih banyak dibelanjakan untuk keperluan pekerjaannya.

Motivasi adalah setiap usaha yang dilakukan untuk menimbulkan motif pada diri seseorang (Padmowiharjo,1999:135) oleh karena itu dikenal ada dua macam motivasi yaitu motivasi instrinsik dan motivasi ekstrinsik dalam penelitian ini. Motivasi instrinsik responden sedang untuk menjadi WTS, sedangkan motivasi ekstrinsiknya untuk bekerja sebagai WTS terlihat rendah. Hasil uji Koefisien Konkordansi Kendall $W$ antara motivasi instrinsik WTS dengan pengetahuan tentang HIV/AIDS adalah $\mathrm{W}=0,93$ pada alfa 
Jurnal Penyuluhan, Maret 2009 Vol. 5 No. 1

0,01, sedangkan Hasil uji Konkordansi Kendall $W$ antara motivasi ekstrinsik WTS dengan pengetahuan tentang HIV/AIDS adalah $\mathrm{W}=0,86$ pada alfa 0,01 . Hasil analisis tersebut menggambarkan bahwa ada hubungan antara motivasi yang dimiliki WTS dengan pengetahuan tentang HIV/AIDS.

Tingginya persepsi hidup mereka yang masih sangat ideal tentang peranan wanita dalam rumahtangga masih terlihat nyata. Hal ini menggambarkan sekumpulan tugas pokok dan fungsi wanita sebagai ibu rumahtangga yang berhubungan dengan hal-hal kerumahtanggaan, sosial, aspek ekonomis dan kasih sayang sesuai dengan status jender wanita pada umumnya. Dengan nilai $W$ tinggi mengemukakan tingkat kesepakatan yang tinggi tentang bahaya HIV/AIDS pada kesehatan manusia.

Pengalaman seseorang akan memberikan kontribusi terhadap minat dan harapannya untuk belajar yang lebih baik. Lamanya responden bekerja menjadi WTS tergolong sangat lama, rata-rata pengalaman bekerja satu tahun. Pengalaman yang relatif lama menggambarkan bahwa WTS cukup banyak memiliki pengetahuan yang ditekuninya selama ini. Hasil uji Konkordansi Kendall W antara lama bekerja sebagai WTS dengan pengetahuan tentang HIV/AIDS sangat nyata $\mathrm{W}=0,90$ pada alfa 0,01 . Hasil analisis tersebut menggambarkan bahwa ada hubungan antara lama bekerja yang dimiliki WTS dengan pengetahuan tentang HIV/AIDS. Hasil penelitian tersebut menunjukkan bahwa semakin lama seseorang menekuni pekerjaan, akan merasa semakin berkurang motivasinya untuk melakukan pekerjaannya. Hal ini mereka nyatakan akan sadar dan keluar dari pekerjaannya sebagai WTS apabila keluar dari panti. Hal ini sesuai tujuan panti rehabilitasi itu sendiri, untuk menyadarkan mereka, atau karena usianya yang mulai tua, sehingga sulit bersaing dengan yang lebih muda.

Faktor pendukung WTS bertahan pada pekerjaannya adalah rendahnya tingkat kekerasan dari pelanggan terhadap mereka. Hasil penelitian, ditemukan sebagian besar atau tujuh puluh enam persen, responden tidak pernah mendapatkan perlakuan kekerasan seksual. Hasil uji Konkordansi Kendall W yang tinggi antara intensitas mendapat perlakuan kekerasan dengan pengetahuan tentang HIV/AIDS. Hasil analisis tersebut menggambarkan terdapat hubungan antara banyaknya mendapat perlakuan kekerasan seksual dari pelanggan dengan pengetahuan HIV/AIDS.

Sebanyak 38\% WTS berasal dari latar belakang ekonomi keluarga sedang, sebagian kecil dari latar belakang ekonomi rendah dan selebihnya berasal dari keadaan ekonomi keluarga tinggi. Hal ini didukung oleh pernyataan Parrinder (2005:97) para pelacur kadang-kadang hidup sangat kaya. Hasil uji Konkordansi Kendall $W$ hubungan sangat nyata antara keadaan ekonomi keluarga WTS dengan pengetahuan tentang HIV/AIDS.

Berikutnya tata nilai (norma) yang dianut WTS. Dalam melaksanakan hubungan sosial, banyak aturan dan norma yang mengatur hak dan kebebasan manusia. Norma agama, norma masyarakat, tata cara adat, aturan negara dan lainnya. Seperti hilangnya norma-norma kehidupan itu menjadi faktor utama yang mendorong mereka terjun ke dalam dunia prostitusi. Hal ini diduga terdapat hubungan antara kepatuhan terhadap norma dengan pengetahuan tentang HIV/AIDS.

Hasil penelitian, lingkungan sosial daerah asal, WTS tidak berpengaruh terhadap mereka terjun ke dalam dunia prostitusi. Sebagian besar responden berasal dari daerah yang tersebar di seluruh daerah di Jawa Barat. Hal ini didukung hasil penelitian Sriwidodo (1997) bahwa peserta pembinaan berasal dari berbagai daerah di wilayah Jawa Barat, tidak dominan pada satu tempat atau daerah.

Sebagian responden menempuh jarak dari tempat tinggal ke tempat bekerja sebagai WTS cukup jauh, dengan rata-rata 7,4 kilometer. Hal ini menggambarkan dengan jarak yang cukup jauh responden merasa leluasa untuk berbuat sesuatu atau melakukan kegiatan menjadi WTS, atau mungkin saja mereka sangat memerlukan pekerjaan semacam ini meskipun jauh dari tempat tinggalnya.

Semakin tingginya intensitas interaksi dengan WTS lain cukup berpengaruh, minimal 2 kali, maksimal 6 kali pertemuan dengan rata- 
rata 4 kali bertemu dalam satu minggu, sebab dari interaksi dengan WTS lain yang dibicarakan dalam pertemuan tersebut adalah masalah pekerjaan.

Para WTS diajari cara berhubungan seksual (40\%). Minimum mereka diajari 5 kali, dan maksimum 21 kali. Rata-rata 9 kali selama menjadi WTS diajari cara-cara melakukan hubungan seks. Hal seperti inilah yang diduga para WTS selalu siap untuk memikat dan melayani para pelanggan.

Tingginya intensitas hubungan responden dengan pelanggan dalam satu minggu dengan rata-rata 5 kali bahkan ada yang 10 kali dalam seminggu berdampak pada tingkat pendapatan. Dampak negatif lainnya adalah semakin rentan penularan penyakit tersebut terhadap para WTS. Hal ini diduga para WTS bekerja untuk memperoleh penghasilan semaksimal mungkin, meskipun unsur kesehatan kurang diperhatikan.

Pada hal lain, hasil penelitian tentang persepsi seks sebagai hedonisme rendah dalam penelitian ini, ditemukan bahwa mayoritas responden $(59 \%)$ menyatakan hal itu. Dengan demikian responden melakukan pekerjaan ini bukan untuk mencari kesenangan seksual semata, melainkan faktor ekonomi.

Hasil analisis pengetahuan WTS tentang HIV/AIDS, diperoleh kesepakatan yang tinggi, dan paling penting adalah: 1) Bahaya HIV/AIDS bagi kesehatan, 2) Cara penularan, 3) Cara pencegahan, 4) Pengertian HIV/AIDS, 5) Pengetahuan Kespro, 6) Akibat HIV/AIDS, 7) Hubungan sosial dengan penderita HIV/AIDS, 8) Penyebab AIDS dan infeksi sekunder akibat AIDS, 9) Dampak sosial ekonomi akibat AIDS dan 10) Hubungan narkoba dengan AIDS.

Dari ketujuh belas bidang karakteristik WTS tentang HIV/AIDS adalah keadaan ekonomi keluarga dengan nilai Konkordansi Kendall $W$ sebesar 0,83 pada alfa 0,01, berada pada tingkat paling bawah sedangkan tingkat keeratan paling tinggi dengan nilai sebesar 0,93 pada alfa 0,01 adalah motivasi instrinsik WTS. Hasil rata-rata tingkat keeratan hubungan karakteristik WTS dengan pengetahuan mereka tentang HIV/AIDS adalah sebesar 0,87 pada alfa 0,01 . Hal ini mengemukakan karakteristik WTS berhubungan nyata dengan pengetahuan tentang HIV/AIDS. Selain itu ketujuh belas karakteristik, semuanya menunjukkan hubungan yang sangat erat pada alfa 0,01 . Hal ini menunjukkan bahwa apapun karakteristik mereka berhubungan secara signifikan dengan pengetahuan tentang HIV/AIDS; berarti bahwa upaya peningkatan pengetahuan tentang HIV/AIDS harus dilakukan terhadap semua WTS tanpa memperhatikan karakteristik mereka.

\section{KESIMPULAN}

Karakteristik umum dari WTS adalah umur dewasa, menikah dan pernah menikah, pendidikan formal rendah, rata-rata tingkat pendapatan $\mathrm{Rp}$ 2.382.900, motivasi instrinsik menjadi WTS sedang, motivasi ekstrinsiknya rendah, persepsi hidup sebagai wanita ideal, lamanya menjadi WTS rata-rata setahun, tidak pernah mendapat perlakuan kekerasan seksual, keadaan ekonomi keluarga sedang, kurang patuh terhadap norma, tidak ada pengaruh lingkungan sosial daerah asal, jarak ke tempat bekerja jauh, intensitas hubungan dengan WTS lain sedang, rata-rata diajari hubungan seksual, intensitas hubungan dengan pelanggan tinggi, dan persepsi seks bukan untuk kesenangan.

Pengetahuan WTS tentang HIV/AIDS dan bahayanya pada kesehatan manusia, terdapat tiga karakteristik yaitu: (a) Karakteristik WTS pertama, pengeta-huan tentang HIV/AIDS hanya dikuasai dengan skor 51,44 atau 51,44 $\%$. (b) Karakteristik WTS kedua, pengetahuan tentang HIV/AIDS hanya dikuasai dengan skor 52,74 atau $52,74 \%$. (c) Karakteristik WTS ketiga, pengetahuan tentang HIV/AIDS hanya dikuasai dengan skor 55,53 atau 55,53 $\%$. (d) Skor tertinggi terdapat pada bidangbidang: 1) Bahaya HIV/AIDS bagi kesehatan, 2) Cara penularan, dan 3) Cara Pencegahan.

Tingkat keeratan hubungan karakteristikkarakteristik WTS dengan pengetahuan mereka tentang HIV/AIDS dan bahayanya pada kesehatan manusia, berdasarkan Nilai $W$, antara $0,83-0,93$, rata-rata Nilai $W=0,87$. Artinya terdapat hubungan sangat nyata positif 
Jurnal Penyuluhan, Maret 2009 Vol. 5 No. 1

antara karakteristik WTS dengan

Pengetahuannya tentang HIV/AIDS. Semakin

tinggi tingkat karakteristik WTS semakin ting-

gi pengetahuan mereka tentang HIV/AIDS.

\section{DAFTAR PUSTAKA}

Padmowiharjo, S. 1999. AIDS dan

Penanggulangannya. Jakarta: Studio Driya

Karya.

Sriwidodo, PS. 1997. Persepsi WTS terhadap

Fungsi Keluarga: Studi Kasus di Panti

Rehabilitasi WTS Jawa Barat. Tesis Magister

Sains. Institut Pertanian Bogor. 